Tersedia online di: http://ejournal-balitbang.kkp.go.id/index.php/jra

\title{
PERFORMA PEMIJAHAN IKAN BELIDA (Notopterus chitala) MELALUI INDUKSI HORMON HCG DAN LHRH
}

\author{
Lies Setijaningsih\#, Jojo Subagja, Deni Radona, Brata Pantjara, Anang Hari Kristanto, dan \\ Yohanna Retnaning Widyastuti
}

Balai Riset Perikanan Budidaya Air Tawar dan Penyuluhan Perikanan

Jl. Sempur No. 1, Bogor 16129

(Naskah diterima: 20 Maret 2018; Revisi final: 16 Mei 2018; Disetujui publikasi: 16 M ei 2018)

\begin{abstract}
ABSTRAK
Permintaan ikan belida cukup tinggi untuk memenuhi kebutuhan konsumsi dan bahan baku olahan makanan yang masih mengandalkan tangkapan dari alam. Tingginya eksploitasi mengakibatkan populasi ikan dari tahun ke tahun semakin berkurang dan terancam punah. Teknologi pembenihan ikan belida dengan penggunaan hormon diduga dapat meningkatkan produksi larva untuk keperluan budidaya. Penelitian dilakukan untuk mengevaluasi performasi pemijahan ikan belida secara alami dan buatan melalui induksi hormon HCG dan LHRH analog. Pemijahan alami dan buatan dilakukan menggunakan induk betina sebanyak enam ekor dan jantan tiga ekor (rasio 2:1). Induk yang digunakan berukuran panjang $46 \pm 5 \mathrm{~cm}$ dan bobot $2.209 \pm 623 \mathrm{~g}$. Pemijahan buatan dilakukan dengan induksi hormon HCG dosis $500 \mathrm{IU} / \mathrm{kg}$ dan LHRH analog dosis $0,5 \mathrm{~mL} / \mathrm{kg}$. Penyuntikan HCG dan LHRH diberikan dengan interval 24 jam. Hasil penelitian menunjukkan pada pemijahan buatan (induksi hormon) diperoleh induk yang memijah sebanyak dua ekor dengan nilai diameter telur $(3,1 \pm 0,3 \mathrm{~mm})$; fekunditas (282-907 butir); derajat pembuahan (21\% $40 \%$; derajat penetasan (56\%75\%); dan sintasan (30\%50\%); sedangkan pada pemijahan alami diperoleh satu ekor induk yang memijah dengan nilai diameter telur (3,5 \pm 0,3 $\mathrm{mm}$ ); fekunditas (1.616 butir); dan derajat pembuahan $(86,7 \%$; selama tiga bulan pengamatan secara intensif dengan frekuensi pemijahan enam kali. Aplikasi teknologi pemijahan dengan menggunakan induksi hormon dapat menghasilkan produk larva pada ikan belida.
\end{abstract}

KATA KUNCl: ikan belida; LHRH analog; HCG; pemijahan alami; pemijahan buatan

ABSTRACT: Performance of Clown Knifefish Notopterus chitala in natural and artificial spawning conditions. By: Lies Setijaningsih, Jojo Subagja, Deni Radona, Brata Pantjara, Anang Hari Kristanto, and Yohanna Retnaning Widyastuti

The demand for fish consumption of Clown Knifefish is considerably high. However, the fish supply for consumption and processed food still relies on wild-caught. Such exploitation has decreased the population of Clown Knifefish to a point that it can become an endangered species. Efforts on the breeding technology of Clown Knifefish through natural and artificial propagation using of hormones have shown promising results. The current study was conducted to evaluate the performance of Clown Knifefish in natural and artificial spawning conditions using the induction of HCG hormone and LHRH analogues. The natural and artificial spawning treatments were conducted using six fish females and three fish males (a ratio of 2:1). The average Broodstocks' size was $46 \pm 5 \mathrm{~cm}$ in length and 2,209 $\pm 623 \mathrm{~g}$ in weight. The artificial spawning was conducted with HCG hormone induction (dose of $500 \mathrm{IU} / \mathrm{kg}$ body weight) and LHRH analogue (dose: $0.5 \mathrm{~mL} / \mathrm{kg}$ ). HCG and LHRH injections were given within 24 hoursinterval. The results showed that theartificial spawning (hormone induction) had successfully caused two broodstock to spawn producing eggs with the diameter of $3.1 \pm 0.3 \mathrm{~mm}$; fecundity of $282-907 \mathrm{eggs}$; fertilization rate of $21 \% 40 \%$ hatching rate of $56 \% 75 \%$ and survival rate of $30 \% 50 \%$ In the natural spawning, one broodstock had spawned with the egg diameter of $3.5 \pm$ $0.3 \mathrm{~mm}$; fecundity of 1,616 eggs; and fertilization rate of $86.7 \%$ This study concludes that spawning technology applications using hormonal induction can increase the production larvae of Clown Knifefish broodstock.

\section{KEYWORDS: Clown Knifefish; LHRH analogue; HCG; natural spawning; artificial spawning}

\footnotetext{
\# Korespondensi: Balai Riset Perikanan Budidaya Air Tawar dan

Penyuluhan Perikanan. Jl. Sempur No. 1, Bogor 16129,

Indonesia.

Tel. + 622518313200

E-mail: liessetijaningsih@ yahoo.com
} 


\section{PENDAHULUAN}

Ikan belida Notopterus chitala merupakan ikan asli perairan Indonesia dengan distribusi sebaran di Pulau Jawa, Sumatera, dan Kalimantan. Selain itu, ikan belida pernah dilaporkan keberadaan populasinya di negaranegara Asia seperti Thailand, Kamboja, Vietnam, dan Malaysia (Wibowo, 2011; Kottelat et al., 1993). Ikan ini memiliki nilai ekologi dan ekonomis tinggi sebagai ikan konsumsi dan bahan baku olahan makanan. Sejauh ini untuk memenuhi kebutuhan konsumsi dan bahan baku olahan makanan seperti kerupuk dan empekempek masih mengandalkan tangkapan dari alam sehingga distribusi sebarannya sudah dikategorikan sebagai komoditas langka atau bahkan hampir punah.

Beberapa penelitian tentang ikan belida sudah banyak dilakukan seperti aspek biologi yang meliputi makanan, reproduksi, dan habitat (Adjie \& Utomo, 1994; Adjie et al., 1999; Sunarno, 2002), aspek lingkungan (Setijaningsih \& Sutrisno, 2013; Nuryadi \& Setijaningsih, 2014), serta penelitian terkait aspek genetik melalui analisis protein (Madang, 1999).

Dalam meningkatkan produktivitas ikan belida perlu dilakukan pengembangan teknologi budidaya ikan belida dari kehidupan insitu ke budidaya secara terkontrol. Salah satunya yaitu dengan menggunakan induksi hormon dalam mempercepat proses maturasi. Penelitian untuk proses maturasi pada ikan-ikan asli perairan Indonesia dengan menggunakan hormon sudah banyak dilakukan antara lain pada ikan gabus (Ath-thar et al., 2017), ikan betok (Yulisari et al., 2018; Maidie et al., 2015), ikan nilem (Radona et al., 2011), ikan torsoro (Asih et al., 2004), ikan tambakan (Radona et al., 2014), dan ikan baung (Supriyadi, 2005). Pada ikan belida, proses maturasi dengan menggunakan induksi hormon sudah dilakukan juga namun belum optimal. Penelitian Kristanto \& Subagja (2010) melaporkan bahwa ikan belida yang diinduksi dengan hormon LHRH analog 1,5 mL/kg dan HCG $500 \mathrm{IU} / \mathrm{kg}$ dapat meningkatkan kematangan gonad, akan tetapi belum berhasil dipijahkan. Hasil yang sama dilakukan Pamungkas (2006) dengan menggunakan hormon LHRH analog $25 \mathrm{mg} / \mathrm{kg}$ dan 17á-metiltestosteron 150 $\mathrm{mg} / \mathrm{kg}$. Aplikasi teknologi pembenihan ikan belida dengan induksi hormon dapat mendukung pencapaian target dan untuk meningkatkan produksi dalam mencegah terjadinya kepunahan spesies (species extinction). Penelitian ini bertujuan untuk mengevaluasi performa pemijahan ikan belida secara alami dan buatan melalui induksi hormon HCG dan LHRH analog.

\section{BAHAN DAN METODE}

Penelitian dilakukan di Instalasi Riset Toksikologi dan Lingkungan Budidaya Cibalagung, unit pelaksana teknis Balai Riset Perikanan Budidaya Air Tawar dan
Penyuluhan Perikanan Bogor dan Balai Perikanan Budidaya Air Tawar, Mandiangin, Kalimantan Selatan.

\section{Ikan Uji}

Induk ikan belida yang digunakan adalah sebanyak 18 ekor (12 betina dan enam jantan) dengan ukuran panjang $46 \pm 5 \mathrm{~cm}$ dan bobot $2.209 \pm 623 \mathrm{~g}$. Induk belida diperoleh dari dua tempat yaitu Cisalak, Kabupaten Subang dan Kampar, Kabupaten Kampar. Pemilihan induk ikan belida mengacu dari penelitian yang pernah dilakukan oleh Setijaningsih \& Sutrisno (2013).

\section{Maturasi Induk Ikan Belida}

Pemeliharaan induk ikan belida dilakukan pada kolam tembok dengan luas $16,5 \mathrm{~m}^{2}$ dengan kedalaman 1,2 m. Pakan yang diberikan berupa pakan "hidup" yakni benih ikan mas, nila, dan nilem. Selain itu, diberikan pakan berupa udang dalam bentuk beku (mati). Pemberian pakan dilakukan sebanyak 5\%dari biomassa dengan frekuensi dua kali sehari yaitu pagi dan sore. Dalam proses percepatan maturasi gonad ikan belida, pakan yang diberikan diperkaya dengan tambahan nutrien berupa vitamin $\mathrm{C}$ dan mineral dengan rasio $1 \mathrm{~kg}$ pakan: $150 \mathrm{~g}$ vitamin dan mineral. Vitamin dan mineral dicampur menggunakan media air, kemudian disemprotkan ke dalam pakan.

\section{Teknik Pemijahan Ikan Belida}

Pemijahan induk ikan belida dilakukan secara al ami dan buatan. Sebelum pemijahan, dilakukan penentuan tingkat kematangan induk ikan belida dengan cara pengambilan telur dalam gonad ikan melalui kanulasi, contoh telur diamati meliputi diameter telur. Induk ikan belida yang terpilih digunakan dalam percobaan pemijahan alami dan buatan. Pemijahan alami dan buatan dilakukan menggunakan induk betina ikan belida sebanyak enam ekor dan induk jantan sebanyak tiga ekor dengan rasio satu jantan dan dua betina yang sekaligus digunakan sebagai ulangan individu. Induk yang digunakan diberi tanda dengan chip untuk memudahkan pegamatan. Pada pemijahan buatan, induk betina ikan belida yang matang gonad (TKG 24) diinduksi dengan hormon HCG dosis $500 \mathrm{IU} / \mathrm{kg}$ dan LHRH analog dosis $0,5 \mathrm{~mL} / \mathrm{kg}$. Induksi hormon LHRH analog dilakukan 24 jam setelah induksi HCG (Kristanto \& Subagja, 2010). Hormon LHRH analog diberikan dua kali dengan interval waktu dari penyuntikan kesatu ke penyuntikan kedua selama enam jam, proporsi pemberian hormon yaitu $40 \%$ pada penyuntikan kesatu dan 60\%pada penyuntikan kedua.

Pada pemijahan alami, diberikan substrat sebagai tempat penempelan telur ikan yang terbuat dari papan, dibentuk segi empat ukuran $100 \mathrm{~cm} \times 50 \mathrm{~cm}$ 
(Setijaningsih \& Sutrisno, 2013). Substrat papan yang sudah ditempeli telur kemudian diangkat dan dibilas dengan air bersih, setelah itu dimasukkan ke dalam akuarium dan diberi aerasi (Gambar 1). Pada pemijahan buatan, telur yang diperoleh diinkubasi pada akuarium berukuran $60 \mathrm{~cm} \times 40 \mathrm{~cm} \times 30 \mathrm{~cm}$ dengan ketinggian air $20 \mathrm{~cm}$. Suhu air yang digunakan selama inkubasi telur $28^{\circ} \mathrm{C}$. Parameter yang diamati pada proses pemijahan yaitu panjang total, bo bot awal, bobot akhir, TKG, frekuensi pemijahan ( $\%$, fekunditas (butir/ekor), derajat pembuahan (persentase telur yang dibuahi dari telur yang diovulasikan; \%. Selain itu, pada pemijahan buatan dilakukan juga pengamatan derajat penetasan (persentase jumlah telur yang menetas dari jumlah telur yang dibuahi; \%, panjang (cm), dan bobot larva (g). Sampel yang digunakan untuk parameter panjang dan bobot larva sebanyak 30 ekor, menggunakan alat ukur dan timbangan dengan ketelitian 0,001 g.

\section{Analisis Data}

Data diperoleh dengan cara sampling, data biologis dilakukan dengan penimbangan bo bot dan pengukuran panjang pada induk. Data yang diperoleh kemudian ditabulasi dan dianalisis dengan bantuan program excel dan dianalisis secara deskriptif.

\section{HASIL DAN BAHASAN}

\section{Perkembangan Induk Ikan Belida}

Hasil pengamatan maturasi gonad dilakukan selama tiga bulan pemeliharaan disajikan pada Tabel 1 dan 2 . Pada proses pemijahan alami, kondisi induk mengalami peningkatan pada karakter bobot sebesar $7,77 \mathrm{~g}$ atau $0,4 \%$ dari bobot rata-rata awal pemeliharaan sebesar 2.209,56 \pm 660,96 g menjadi 2.217,22 \pm $621,32 \mathrm{~g}$ (Tabel 1). Pada proses pemijahan dengan induksi hormon, kondisi induk mengalami peningkatan pada bo bot sebesar $9,22 \mathrm{~g}$ atau $0,5 \%$ dari bobot rata-rata awal pemeliharaan sebesar $2.227,78$ $\pm 605,589$ g menjadi $2.237,00 \pm 570,04 \mathrm{~g}$ (Tabel 2).

Pada pemijahan alami diperoleh satu ekor induk yang siap memijah dengan ukuran bobot sebesar $1.500 \mathrm{~g}$ sedangkan pada pemijahan buatan diperoleh dua ekor induk betina dengan bobot masing-masing $1.460 \mathrm{~g}$ dan $1.418 \mathrm{~g}$. Ketiga ekor induk betina tersebut mengalami peningkatan bobot berkisar 8-10 g. Peningkatan bobot ikan sejalan dengan perkembangan tingkat kematangan gonad (TKG) dari TKG-2 dan 3 menjadi TKG-3+ dan 4 dan diikuti juga dengan pertumbuhan diameter oosit menjadi rata-rata 3,1 \pm $0,3 \mathrm{~mm}$. Kristanto et al. (2008) melaporkan bahwa ikan belida bisa memijah sepanjang tahun dengan puncak pemijahan terjadi pada musim kemarau. Selain itu, proses maturasi gonad ikan dapat dipengaruhi oleh faktor eksternal dan internal. Faktor internal antara lain spesies, umur, dan ketersediaan hormon, sedangkan faktor eksternal dipengaruhi oleh lingkungan, suhu, dan jenis makanan (Santoso, 2009).

\section{Pemijahan Alami}

Pada satu bulan pertama pemeliharaan induk dapat memijah secara alami dan telur didapatkan pada papan substrat (Gambar 1). Proses pemijahan induk belida mulai menempelkan telur tidak diketahui waktu yang tepatnya.

Hasil pengamatan induk ikan belida selama penelitian (tiga bulan) di kolam tembok dengan pemijahan alami menunjukkan persentase frekuensi pemijahan tertinggi $(50,00 \%)$ pada bulan kedua pemeliharaan sebanyak tiga kali, dan terendah pada bulan ketiga pemeliharaan yang diperoleh hanya sekali bertelur (16,67\% (Gambar 2).

Fekunditas yang dihasilkan pada pemijahan ini didapat dari perhitungan secara manual pada telur yang diovulasikan dan menempel pada substrat. Dari hasil pengamatan telur ikan belida diperoleh ukuran diameter 3,5 0,3 mm. Nilai ini sama halnya dengan hasil penelitian Srivastava et al. (2012) yang melaporkan bahwa telur ikan belida memiliki diameter 3,5 $\pm 0,5$ $\mathrm{mm}$. Nilai Fekunditas pada suatu spesies ikan dapat berbeda antara satu individu dengan individu lainnya. Fekunditas mempunyai keterpautan dengan umur, panjang, dan bobot individu. Jumlah fekunditas terbanyak terdapat pada bulan kedua pemeliharaan sejumlah 932 butir/ekor, pada bulan ketiga pemeliharaan masing-masing sejumlah 459 dan 225 butir/ekor (Gambar 3). Menurut Nikolsky (1963), bahwa fekunditas pada setiap individu betina tergantung pada umur, ukuran, spesies, dan kondisi lingkungan, seperti ketersediaan pakan. Fekunditas akan menurun sejalan dengan mulai menurunnya kondisi ikan yang memengaruhi kualitas dan kuantitas telur yang dihasilkan. Pada penelitian Santoso (2009) dan Sunarno (2002) fekunditas yang dihasilkan ikan belida dengan ukuran < $1.000 \mathrm{~g}$ berkisar 250-500 butir dengan rata-rata 290 butir/ekor. Penelitian lain, Kohinoor et al. (2012) dan Gustomi et al. (2016) menghasilkan rata-rata 1.000 butir telur pada induk belida dengan ukuran bo bot sekitar $2.000 \mathrm{~g}$, sedangkan pada penelitian Hossain et al. (2006) melaporkan jumlah fekunditas yang dihasilkan dari induk dengan ukuran $>4.000$ g sebanyak 5.761 butir.

Selanjutnya disebutkan bahwa data fekunditas signifikan pada musim hujan ditunjukkan dengan lebih banyak telur pada musim hujan. Menurut Cholik et al. (2005), ikan belida memijah pada musim penghujan, namun demikian juga terkait dengan kualitas telur ikan belida. 
Tabel 1. Panjang, bobot (awal dan akhir), jenis kelamin, dan tingkat kematangan gonad (TKG) induk ikan belida di kolam dengan sistem pemijahan alami

Table 1. Length, weight (initial and final), sex, gonad maturation stage(TKG) of Clown Knifefish broodstock cultured in the pond with natural spawning system

\begin{tabular}{ccccccc}
\hline No. & $\begin{array}{c}\text { Panjang total } \\
\text { Total length } \\
\mathbf{( c m})\end{array}$ & $\begin{array}{c}\text { Bobot awal } \\
\text { Initial weight } \\
\mathbf{( g )}\end{array}$ & $\begin{array}{c}\text { Bobot akhir } \\
\text { Final weight } \\
\mathbf{( g )}\end{array}$ & $\begin{array}{c}\text { Kelamin } \\
\text { Sex }\end{array}$ & TKG & $\begin{array}{c}\text { Perlakuan } \\
\text { Treatments }\end{array}$ \\
\hline 1 & 56.2 & 3,166 & 3,170 & Jantan (Male) & Sperma (Sperm) 0 & A \\
2 & 50.1 & 2,715 & 2,719 & Jantan (Male) & Sperma (Sprem) + & A \\
3 & 49.7 & 2,570 & 2,578 & Betina (Female) & TKG 2 & A \\
4 & 47.4 & 2,370 & 2,376 & Betina (Female) & TKG 1 & A \\
5 & 53.3 & 2,825 & 2,834 & Betina (Female) & TKG2 & A \\
6 & 40.6 & 1,500 & 1,511 & Betina (Female) & TKG2 & A \\
7 & 40.0 & 1,410 & 1,420 & Jantan (Male) & Sperma (Sprem) + & A** \\
8 & 42.9 & 1,830 & 1,837 & Betina (Female) & TKG 1 & A \\
9 & 41.2 & 1,500 & 1,510 & Betina (Female) & TKG 2 & A* \\
\hline X & 46.82 & $2,209.56$ & $2,217.11$ & & & \\
\hline SD & 5.93 & 660.96 & 621.32 & & & \\
\hline
\end{tabular}

Keterangan: A: Perlakuan pemijahan alami, $A^{*}:$ Induk yang diduga memijah (papila berwarna merah), $A$ **: induk jantan yang dipergunakan untuk pemijahan buatan pada perlakuan $B$, sperma 0 : tidak ada sperma, dan sperma + : ada sperma

Remarks: $\quad A$ : natural spawning treatment, $A^{*}$ : broodstock allegedly spawning (red papilla), $A^{* *:}$ male broodstock was used for spawning in treatment $B$, sperm 0 : no sperm produced, and sperm + : sperm produced

Tabel 2. Panjang, bobot (awal dan akhir), jenis kelamin, dan tingkat kematangan gonad (TKG) induk ikan belida di kolam dengan sistem pemijahan menggunakan induksi hormon

Table 2. Length, weight (initial and final), sex, gonad maturation stage (TKG) of Clown Knifefish broodstock cultured in the pond with artificial spawning system using hormonal induction

\begin{tabular}{ccccccc}
\hline No. & $\begin{array}{c}\text { Panjang total } \\
\text { Total length } \\
(\mathbf{c m})\end{array}$ & $\begin{array}{c}\text { Bobot awal } \\
\text { Initial weight } \\
\mathbf{( g )}\end{array}$ & $\begin{array}{c}\text { Bobot akhir } \\
\text { Final weight } \\
\mathbf{( g )}\end{array}$ & $\begin{array}{c}\text { Kelamin } \\
\text { Sex }\end{array}$ & TKG & $\begin{array}{c}\text { Perlakuan } \\
\text { Treatments }\end{array}$ \\
\hline 1 & 54 & 2,855 & 2,861 & Jantan (Male) & Sperma (Sperm) + & B \\
2 & 54 & 3,150 & 3,158 & Jantan (Male) & Sperma (Sperm) + + & B** \\
3 & 47 & 2,375 & 2,381 & Betina (Female) & TKG 3 & B \\
4 & 49 & 2,560 & 2,571 & Betina (Female) & TKG 1 & B \\
5 & 47 & 2,450 & 2,459 & Betina (Female) & TKG 3 & B \\
6 & 45 & 2,000 & 2,013 & Betina (Female) & TKG 1 & B \\
7 & 46 & 1,800 & 1,812 & Jantan (Male) & Sperma (Sperm) + + & B** \\
8 & 40 & 1,450 & 1,460 & Betina (Female) & TKG 3-4 & B** \\
9 & 41 & 1,410 & 1,418 & Betina (Female) & TKG 2-4 & B** \\
\hline X & 47,00 & $2,227.78$ & 2,237 & & & \\
\hline SD & 4.90 & 605.59 & 570.04 & & & \\
\hline
\end{tabular}

Keterangan: B: perlakuan pemijahan buatan, $B$ **: induk yang disuntik (jantan dan betina), sperma + : produksi sperma dikit, dan sperma ++ : produksi sperma banyak

Remarks: B: artificial spawning treatment; $B^{* *}$ : broodstock was injected (male and female), sperm + : little sperm production, and sperm ++ : many sperm production 


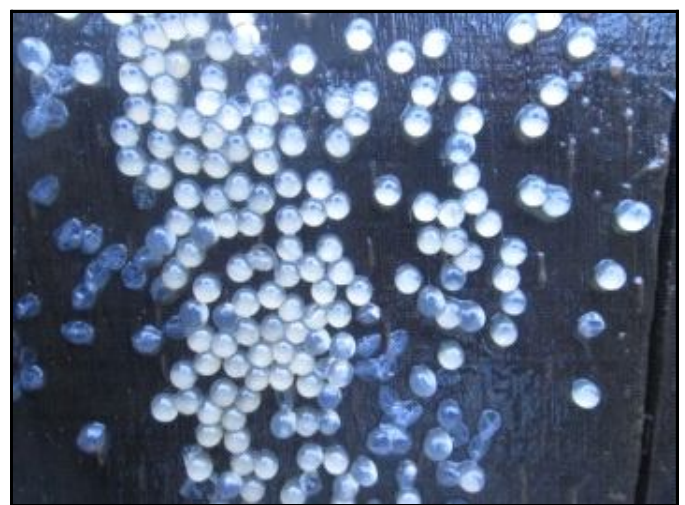

(A)

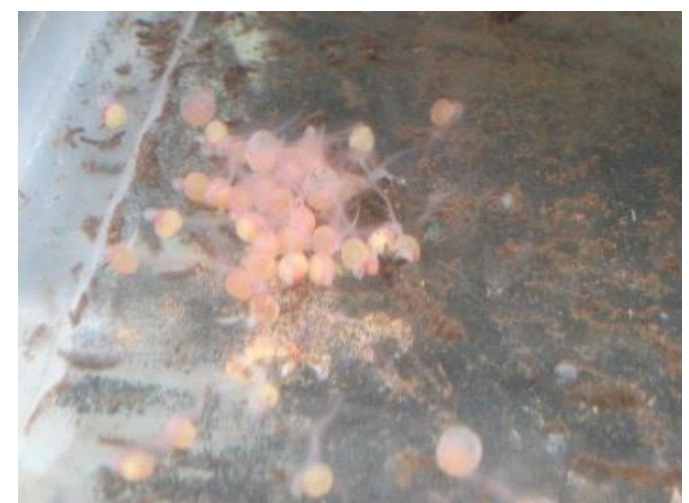

(B)

Gambar 1. Telur ikan belida hari pertama pengambilan substrat dari kolam pemeliharaan; A) telur yang tidak terbuahi dan B) telur yang terbuahi.

Figure 1. Clown Knifefish eggs of the first day post bottom substrate collection from the rearing pond; A) unfertilized eggs and B) fertilized eggs.

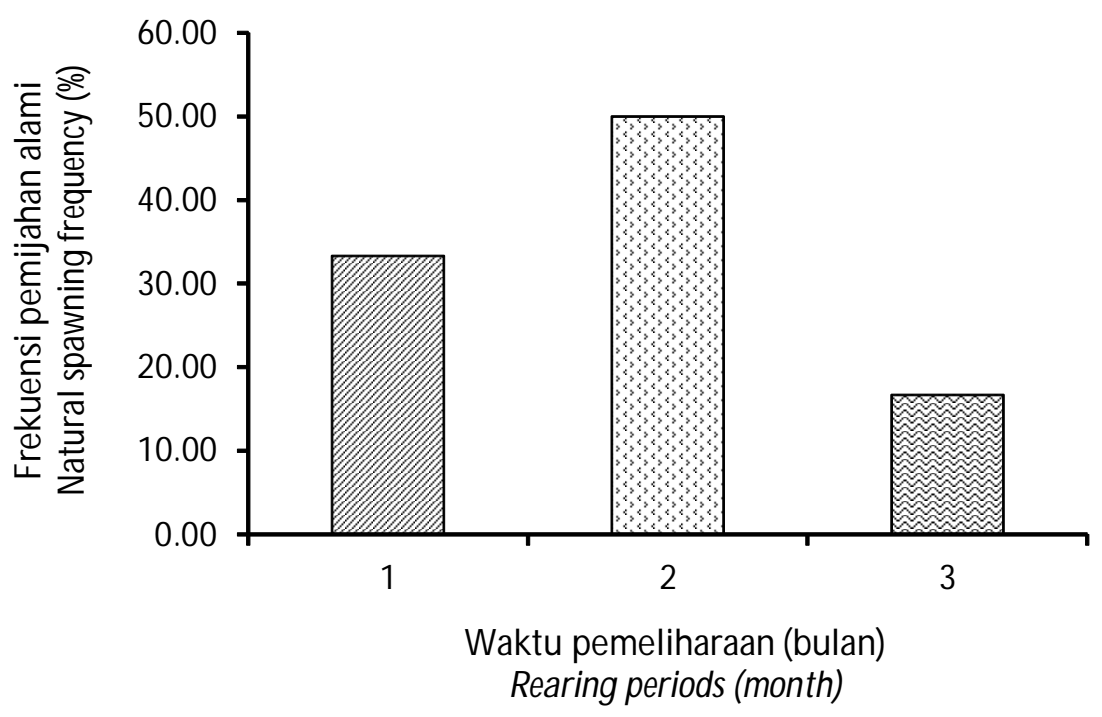

Gambar 2. Frekuensi pemijahan alami ikan belida.

Figure 2. Natural spawning frequency of Clown Knifefish.

Pengamatan terhadap kondisi telur yang diinkubasi dilakukan selama 3-5 hari setelah proses pembuahan. Telur yang telah dibuahi berwarna kuning mengkilap, sedangkan telur yang tidak dibuahi berwarna putih keruh. Hasil perhitungan derajat pembuahan diperoleh pada setiap bulan pemeliharaan masing-masing adalah $90 \% 80 \%$ dan $90 \%$ (Gambar 4). Pada saat pengamatan telur, terdapat juga telur-telur yang posisi intinya sudah ditepi atau bahkan kosong. Hal ini dimungkinkan pada beberapa induk memiliki telur dengan tingkat kematangan yang tidak seragam dan sedikitnya sperma yang dihasilkan oleh induk jantan. Selain itu, faktor penyebab rendahnya tingkat pembuahan karena waktu pengamatan dilakukan di luar musim pemijahan ikan belida yaitu musim penghujan (Kristanto et al., 2008).

Pengamatan pada telur yang menetas ini dilakukan mulai dari hari ketiga setelah pembuahan dilakukan sampai tidak terdapat lagi telur yang menetas sampai hari kelima. Telur yang menetas ditandai dengan gerakannya yang memutar, sedangkan telur yang tidak menetas berwarna putih keruh, tidak ada gerakan dan tetap ada di substrat yang pada akhirnya membusuk. Pada penelitian ini, persentase derajat pembuahan yang dihasilkan terbilang tinggi $(86,7 \%)$ dibandingkan dengan penelitian Hossain et al. (2006) yaitu $82,00 \%$ 


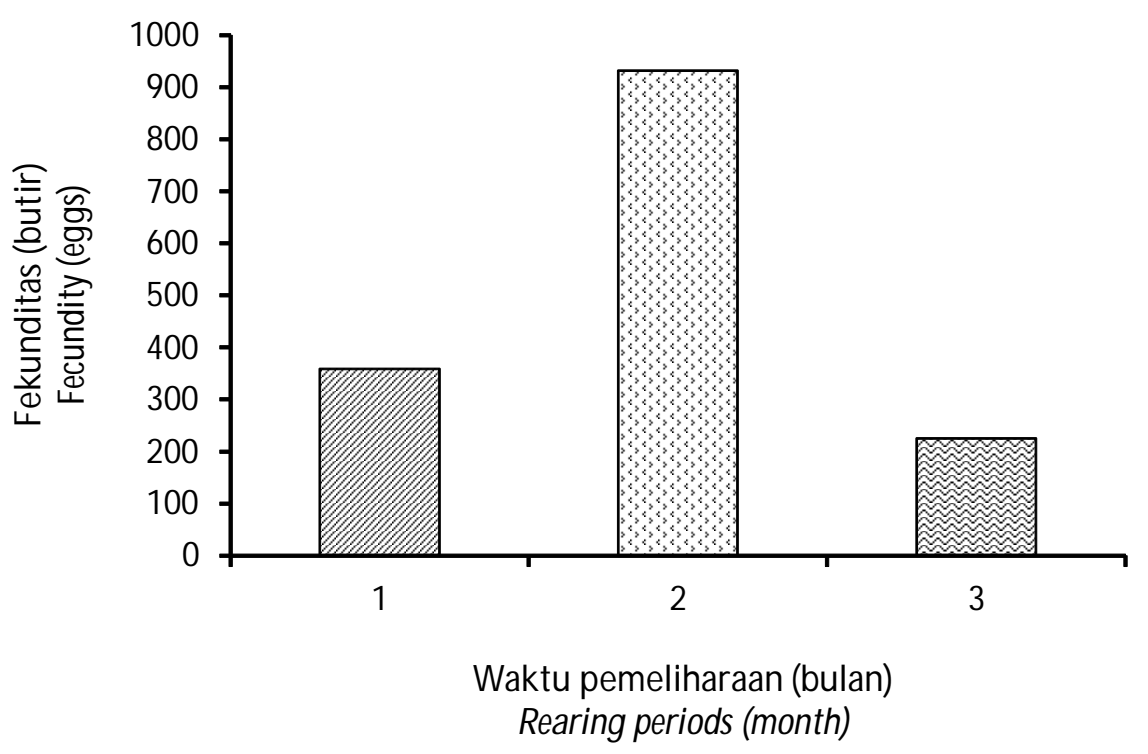

Gambar 3. Nilai fekunditas ikan belida.

Figure 3. Fecundity value of Clown Knifefish.

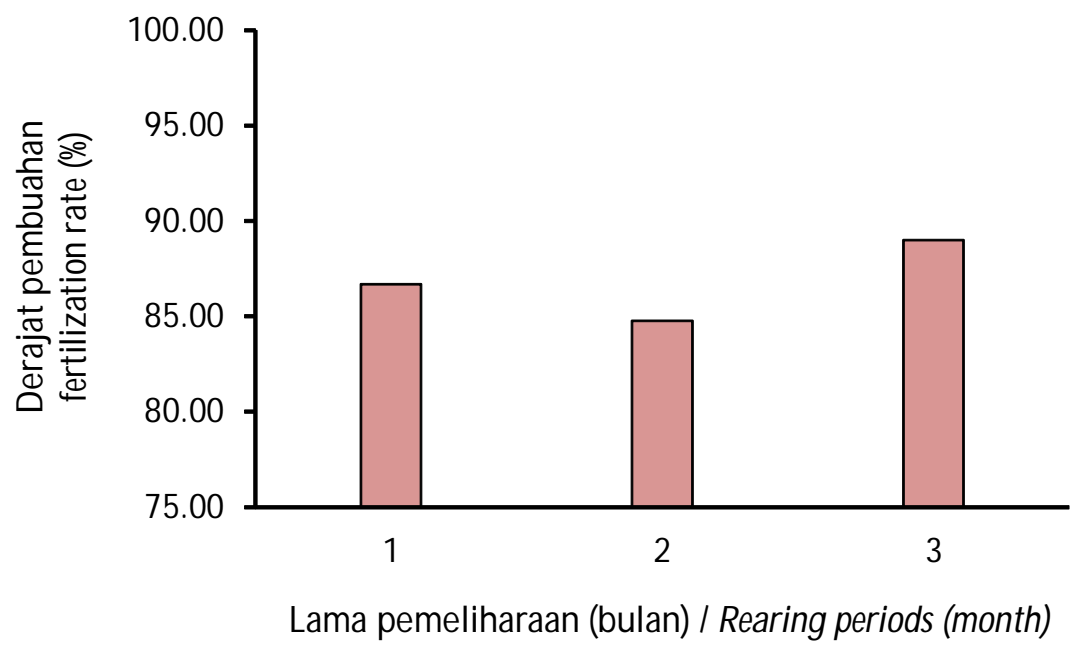

Keterangan: Warna bar pada gambar merupakan individu ikan belida yang memijah Remarks: Color bar in the figure is an individual spawn of clown knifefish

Gambar 4. Nilai derajat pembuahan ikan belida hasil pemijahan alami.

Figure 4. Value of fertilization rate of natural spawning of Clown Knifefish.

hal ini karena induk betina ikan belida pada saat proses pemijahan alami terjadi sudah pada fase TKG-4. Daya pembuahan telur dapat dipengaruhi oleh faktor intrinsik dari embrio itu sendiri (Kurcharczky et al., 2014).

\section{Pemijahan Buatan dengan Induksi Hormon}

Karakteristik biologi reproduksi ikan belida hasil pemijahan dengan induksi hormon disajikan pada Tabel 3. Setelah tujuh jam 30 menit, induk belida betina memijah. Jumlah telur yang diperoleh dari satu induk betina sebanyak 386 butir/ekor, dengan bobot $20 \mathrm{~g}$. Inkubasi telur belida dilakukan pada bak fiber dengan diameter bak $100 \mathrm{~cm}$ dan diisi air sebanyak 30 liter. Telur menetas diinkubasikan selama tiga hari. Lama penetasan yang dihasilkan relatif lebih cepat dibandingkan dengan penelitian Srivastava et al. (2012) yang menyatakan penetasan terjadi pada hari kelima atau keenam setelah pembuahan. Keberhasilan pemijahan buatan dalam menghasilkan larva, karena 
Tabel 3. Karakter biologi reproduksi ikan belida hasil pemijahan dengan induksi hormon HCG dan LHRHa

Table 3. Reproductive biology character of clown knifefish spawning result with HCG hormonal induction and LHRHa

\begin{tabular}{lc}
\hline \multicolumn{1}{c}{$\begin{array}{c}\text { Parameter } \\
\text { Parameters }\end{array}$} & $\begin{array}{c}\text { Hasil pengamatan } \\
\text { Observation result }\end{array}$ \\
\hline Waktu laten pemijahan (jam) / Latent period of spawning (hours) & $13-15$ \\
Fekunditas (butir per ekor) / Fecundity (eggs per individual) & $225-932$ \\
Diameter telur / egg diameter (mm) & $3.2-3.8$ \\
Derajat pembuahan / Fertilization rate (\%) & $21-40$ \\
Derajat penetasan / Hathcing rate (\%) & $56-75$ \\
Panjang larva / Length of larvae (cm) & $1.7-1.9$ \\
Bobot larva / W eight of larvae (g) & $0.0375-0.0379$ \\
Sintasan / Survival rate (\%) & $30-50$ \\
\hline
\end{tabular}

induk ikan belida telah mencapai matang gonad yang sesuai dan dapat menerima rangsangan hormonal. Menurut Zohar (1989), HCG akan merangsang pematangan oosit dan mempercepat aktivitas hormon yang terlibat dalam pematangan telur seperti testosteron, progesteron, dan $17 \alpha$-progesteron. Penggunaan Luteinizing hormon releasing hormon (LHRH) pada pemijahan secara buatan diperuntukkan untuk memacu kelenjar pituitari melepaskan hormon gonadotropin (GTH) setelah kelenjar hipotalamus mendapat tambahan hormon LHRH yang berasal dari eksogenus. GTH di dalam darah merangsang gonad untuk menghasilkan hormon steroid yang memacu untuk pematangan telur dan sperma (Lutz, 2001).

Pemijahan ikan belida secara buatan dapat meningkatkan kinerja reproduksi dan produktivitasnya sehingga dapat menjamin ketersediaan benih untuk budidaya dan mendukung konservasi di alam.

\section{KESIMPULAN}

Aplikasi teknologi pemijahan ikan belida dengan menggunakan induksi hormon dapat meningkatkan produksi dalam pemenuhan ketersediaan benih untuk budidaya dan mendukung konservasi ikan belida di alam.

\section{UCAPAN TERIMA KASIH}

Ucapan terima kasih disampaikan kepada Kementerian Riset Teknologi dan Pendidikan Tinggi yang sudah mendanai penelitian ini melalui DIPA Tahun 2017. Terima kasih juga kepada Sdr. Heppy Aprilistianto dan Sudarmaji yang telah membantu terlaksananya penelitian ini.

\section{DAFTAR ACUAN}

Adjie, S., Husnah, \& Gafar, A.K. (1999). Studi biologi ikan belida Noptoterus chitala di daerah aliran sungai Batang Hari Provinsi Jambi. Jurnal Penelitian Perikanan Indonesia, 5(1), 38-44.

Adjie, S. \& Utomo, A.D. (1994). Aspek biologi ikan belida di sekitar perairan Lubuk Lampam Sumatera Selatan. Prosiding seminar dan penyusunan, pengolahan dan evaluasi hasil penelitian perikanan perairan umum. Loka Penelitian Perikanan Air Tawar Palembang.

Asih, S., Subagja, J., Winarlin, \& Widiyati, A. (2004). Penguasaan teknik pembenihan dan pembesaran ikan batak: Peningkatan kualitas telur melalui perlakuan hormonal pada penyuntikan awal dalam berbagai dosis dan selang waktu berbeda. Laporan Hasil Penelitian Balai Riset Perikanan Budidaya Air Tawar. hlm. 314-323.

Ath-thar, M.H.F., Gustiano, R., Kusmini, I.I., Prakoso, V.A., \& Putri, F.P. (2017). Induksi hormonal maturasi gonad ikan gabus (Channa striata). Jurnal Riset Akuakultur, 12(1), 9-20.

Cholik, F., Jagadraya, A.G., Poernomo, R.P., \& Jauji, A. (2005). Akuakultur tumpuhan harapan masa depan bangsa. Masyarakat Perikanan Nusantara dan Taman Akuarium Air Tawar. Jakarta, 425 hlm.

Gustomi, A., Sulistiono, \& Yonvitner. (2016). Biologi reproduksi ikan belida (Notopterus notopterus Pallas, 1769) di kolong-bendungan Simpur, Pulau Bangka. Jurnal Ilmu Pertanian Indonesia, 21(1), 56-62.

Hossain, Q.Z., Hossain, M.A., \& Parween, S. (2006). Breeding biology, captive breeding and fry nursing of humped featherback (Notopterus chitala). Ecoprint, 13, 41-47. 
Kottelat, M., Kartikasari, S.N., Whitten, A.J., \& Wirjoatmodjo, S. (1993). Freshwater fishes of Western Indonesia and Sulawesi. Edisi dua bahasa. Jakarta: Periplus Editions Limited, 221 pp.

Kristanto, A.H. \& Subagja, J. (2010). Respons induk ikan belida terhadap hormon pemijahan. Prosiding Forum Inovasi Teknologi Akuakultur. Pusat Riset Perikanan Budidaya. Jakarta, hlm. 113-116.

Kristanto, A.H., Nuryadi, Yosmaniar, \& Sutrisno. (2008). Perkembangan telur dan sperma induk ikan belida Notopterus chitala yang dipelihara di kolam. Jurnal Riset Akuakultur, 3(1), 73-82.

Kucharczyk, D., - arski, D., Targoñska, K., fuczyñski, M.J., Szczerbowski, A., Nowosad, J., Kujawa, R., \& Mamcarz, A. (2014). Inducedartificial androgenesis in common tench, Tincatinca (L.), using common carp and common bream eggs. Ital. J. Anim. Sci., 13, 196-200.

Lutz, C.G. (2001). Practical genetic for aquaculture. Fishing News Books, 234 pp.

Madang, K. (1999). Morfologi habitat dan keragaman genetik kerabat ikan belida di perairan Sumatera Selatan. Disertasi. Program Pascasarjana, Institut Pertanian Bogor.

Maidie, A., Sumoharjo., Asra, S.W., Ramadhan, M., \& Hidayanto, D.N. (2015). Pengembangan pembenihan ikan betok (Anabastestusdineus) untuk skala rumah tangga. M edia Akuakultur, 10(1), 3137.

Nikolsky, G.V. (1963). The ecology of fishes. New York: Academic Press.

Nuryadi \& Setijaningsih, L. (2014). Periode penyinaran pembenihan ikan belida Notopterus chitala untuk meningkatkan sintasan. Prosiding Forum Inovasi Teknologi Akuakultur. Pusat Penelitian dan Perikanan Budidaya. Jakarta, hlm. 881-885.

Pamungkas, A.J. (2006). Efektivitas hormon 17 alpha metiltestoteron dan LHRHa dalam mencapai tingkat kematangan gonad siap memijah pada ikan belida. Tesis. Sekolah pasca Sarjana. Institut Pertanian Bogor, $70 \mathrm{hlm}$.

Radona, D., Cahyanti, W., \& Kusmini, I.I. (2014). Teknologi pembenihan ikan tambakan (Helostoma temminckii) di Balai Budidaya Ikan Sentral, Provinsi Kalimantan Barat. Prosiding Forum Inovasi Teknologi Akuakultur, Pusat Penelitian dan Perikanan Budidaya. Jakarta, hlm. 885-891.

Radona, D., Asih, S., \& Sunarno, M.T.S. (2011). Penggunaan ovaprim dalam keberhasilan ovulasi, derajat penetasan dan kelangsungan hidup larva ikan nilem Osteochilus hasselti. Prosiding Seminar Nasional Perikanan, Sekolah Tinggi Perikanan. Jakarta, hlm. 102-106.

Santoso, L. (2009). Biologi reproduksi ikan belida (Chitala lopis) di Sungai Tulang Bawang, Lampung. Berkala Perikanan Terubuk, 37(1), 38-46.

Setijaningsih, L. \& Sutrisno. (2013). Perbaikan teknik perbenihan ikan belida Notopterus chitala melalui rekayasa lingkungan. Laporan Teknis Hasil Penelitian. Balai Penelitian dan Pengembangan Budidaya Air Tawar. Bogor, $31 \mathrm{hlm}$.

Srivastava, S.M., Gopalakrishnan, A., Singh, P.S., \& Pandey, A.K. (2012). Embryonic and larval development of threatened bronze featherback, Notopterus notopterus (Pallas). J. Exp. Zoology, 15(2), 425-430.

Sunarno, M.T.D. (2002). Selamatkan plasma nutfah ikan belida. Warta Penelitian Perikanan, 8(4), 2-7.

Supriyadi. (2005). Efektivitas pemberian HCG dan 17ámetiltestosteron yang dienkapsulasi didalam emulsi terhadap perkembangan gonad ikan baung. Tesis pascasarjana. Institut Pertanian Bogor, $74 \mathrm{hlm}$.

Wibowo, A. (2011). Kajian bioekologi dalam rangka menentukan arah pengelolaan ikan belida Notopterus chitala (Bleeker 1851) di Sungai Kampar, Provinsi Riau. Disertasi. Sekolah Pascasarjana. Institut Pertanian Bogor, $170 \mathrm{hlm}$.

Yulisari, I., Sukendi, \& Nuraini. (2018). The effect of ovaprim and HCG injection with different doses on ovulation and egg quality of climbing pearch (Anabas testudineus). Jurnal Online Mahasiswa Universitas Riau, 5(1), 1-9.

Zohar, Y. (1989). Fish reproduction its physiology and artificial manupulation. In Shilo, M., \& Sarig, S. Fish culture in warmwater system: Problem and trends. Boca raton, Florida: CRC Press. Inc., p. 65-119. 